\title{
STRESS MANAGEMENT DURING CORONA LOCKDOWN AMONG STUDENTS
}

\author{
Anju Ojha \\ Assistant Professor, Geography, Govt. Lohia College, Churu (Rajasthan) India \\ Email: draj2280@gmail.com
}

\begin{abstract}
Lockdown is meant to prevent the spread of infection from one person to another, to protect ourselves and others. It means, not stepping out of the house except for buying necessities, reducing the number of trips outside, and ideally only a single, healthy family member making the trips when absolutely necessary. If there is anyone in the house who is very sick and may need to get medical help, you must be aware of the health facility nearest to you. It is difficult times for all of us as we hear about spread of COVID-19 from all over the world, through television, social media, newspapers, family and friends and other sources. The most common emotion faced by all is fear. It makes us anxious, panicky and can even possibly make us think, say or do things that we might not consider appropriate under normal circumstances.
\end{abstract}

Key words: Stress Management, Lockdown, COVID-19, Anxiety, Panic, and Meditation.

\section{Introduction}

The World Health Organization (WHO) declared the COVID-19 outbreak a global pandemic and many of us, whether infected or not, will choose to isolate themselves in order to protect and check the spread of COVID-19. The capsized travel plans, indefinite isolation, scarce resources and information overload resulted in unwanted stress, depression and anxiety. Modern life is full of stress. Stress on individual differs from person to person. Our environment has undergone changes induced by human beings and human beings failed to cope up with the change nearly every time and on every occasion. Stress is not always bad sometimes a little amount of stress is necessary to achieve a goal. But high level stress is harmful and dangerous to health. In recent times, due to Corona Virus spread a large number of students have experienced high level of stress. To define, 'stress is the body's reaction to change that required a physical, mental or emotional adjustment or response'. In other words, stress is a dynamic condition in which an individual is confronted with an opportunity constraint or demand related to what he or she desires and for which the outcome is perceived to be both uncertain and important. The outbreak of coronavirus has resulted in a nation-wide lockdown. Staying at home all day can be tiring, boring and stressful. The lockdown has especially become a cause of stress and anxiety for those whose businesses are shut down and/or are incurring losses. In such times, doing some meditation and stress-busting activities can be helpful. Meditation is a commonly-used practice to relax and feel less stressed. It is a practice which is considered to be great for boosting mental health.

\section{Impact of Stress}

The outbreak of corona virus disease 2019 (COVID-19) may be stressful for students. Fear and anxiety about a disease can be overwhelming and cause strong emotional disorders in adults and children. Stress is unavoidable in our life, and it is not always bad, a mild stress may increase the student's performance, stress before appearing an exam and interview, target to achieve within the time limits are good examples. But the high level stress is not always desirable. The consequences include physical, psychological, behavioural and mental consequences. 


\section{Methodology}

The study is mainly based on primary data. The primary data is related to college students. The sample population included 200 students from different college student in Churu District. The online mode of primary survey was used to collect data from the students on random basis.

\section{Awareness about Lockdown}

Students were well aware about the lockdown and aspects related to lockdown. The following table shows that 72 per cent students were very well aware about the lockdown and its necessity. But, 22 per cent were still very much confused about the lockdown and its actual meaning for society. Whereas 04 percent have not given any answer. The details are given in the table1.

Table 01: Awareness about Lockdown

\begin{tabular}{|l|c|c|}
\hline Response & Number of Students & Percentage (\%) \\
\hline Yes & 148 & 74 \\
\hline No & 44 & 22 \\
\hline No Response & 08 & 04 \\
\hline Total & 200 & 100 \\
\hline
\end{tabular}

Source: Primary survey (online mode) done by author, 2020

Figure 01: Awareness about Lockdown

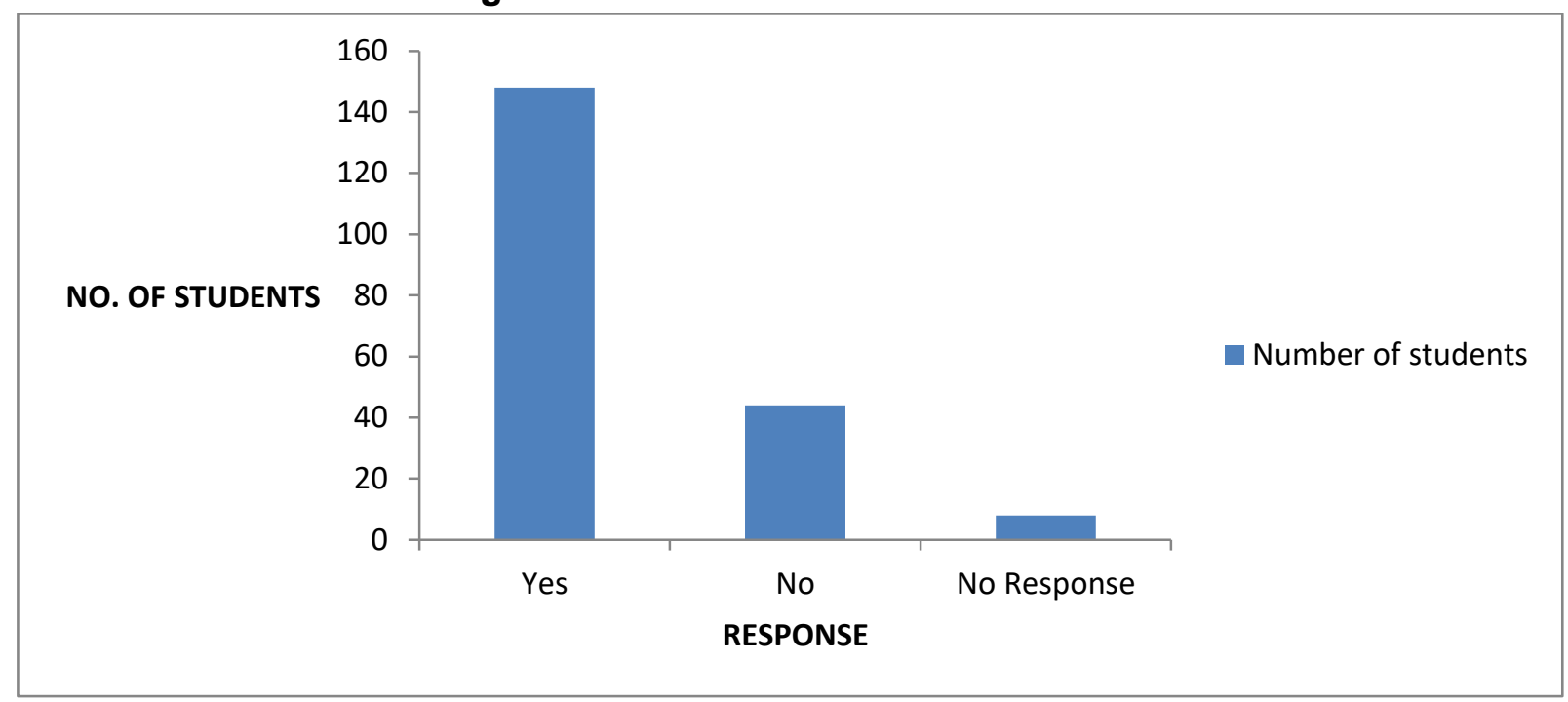

\section{Feelings during the Lockdown}

Feeling this overwhelming stress for a long period of time is often called chronic or longterm stress, and it can impact both physical and mental health. Stress is a response to a threat in a situation, whereas anxiety is a reaction to the stress. Some of students were also facing relationship issues and losing patience with their partners. Students worried for their academic futures. The following table shows that about 35 percent students are feeling very bad. Only 10 percent students are normal, whereas, 52 per cent students were found more or less depressed. The details are given in the table number 02. 
Table 02: Feelings during the Lockdown

\begin{tabular}{|l|c|c|}
\hline Feelings & Number of Students & Percentage (\%) \\
\hline Very Bad & 70 & 35 \\
\hline Normal & 20 & 10 \\
\hline Depressed & 104 & 52 \\
\hline No answer & 16 & 08 \\
\hline Total & 200 & 100 \\
\hline
\end{tabular}

Source: Primary survey (online mode) done by author, 2020

Figure 02: Feelings during the Lockdown

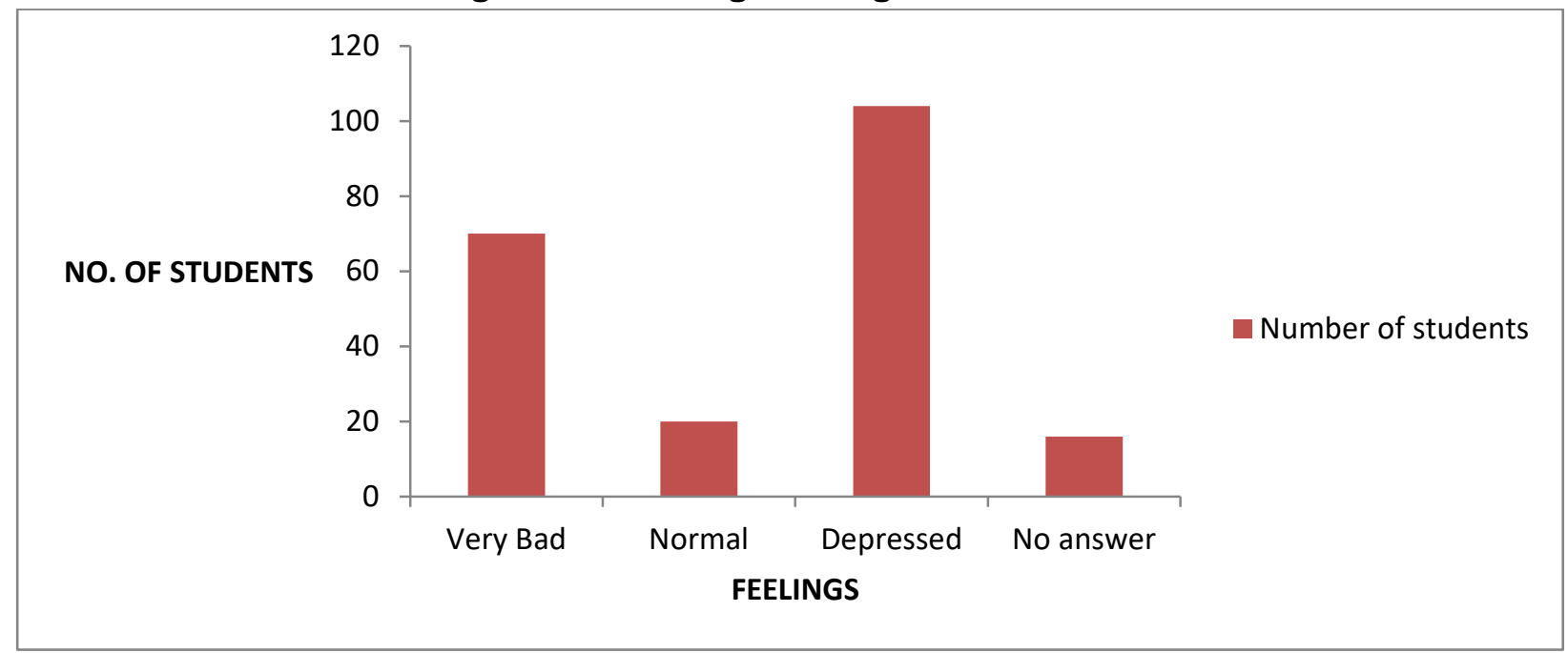

\section{Delay or Postponement of Academic Examinations}

The biggest issue of causing depression is not having their exam i.e. because all exams after 18 March were postponed. The table shows that 100 per cent students have reported that their exams were not completed yet. They don't know when and how these exams will be conducted.

Table 03: Delay or Postponement of Academic Examinations

\begin{tabular}{|l|c|c|}
\hline Response & Number of Students & Percentage (\%) \\
\hline Yes & 00 & 00 \\
\hline No & 200 & 100 \\
\hline Total & 200 & 100 \\
\hline
\end{tabular}

Source: Primary survey (online mode) done by author, 2020

\section{Exam Related Stress and Anxiety Issues}

Though exams have not been completed, lockdown is still continuing up to May end. What will happen after May, nobody knows. They are anxious about how they will get admission in their next new course, or new college or university; all these issues are in most of all students' mind. That is why they are in stress. The students responded that 83 per cent students are feeling stressed due to their non-completion of exam. This situation is very bad not only for students but for their parents also. Only 13 students responded that they don't have any stress. This also depends on the mental level of students and family atmosphere. 
Table 04: Exam Related Stress and Anxiety Issues

\begin{tabular}{|l|c|c|}
\hline Response & Number of Students & Percentage (\%) \\
\hline Yes & 166 & 83 \\
\hline No & 26 & 13 \\
\hline No Response & 08 & 04 \\
\hline Total & 200 & 100 \\
\hline
\end{tabular}

Source: Primary survey (online mode) done by author, 2020

Figure 03: Exam Related Stress and Anxiety Issues

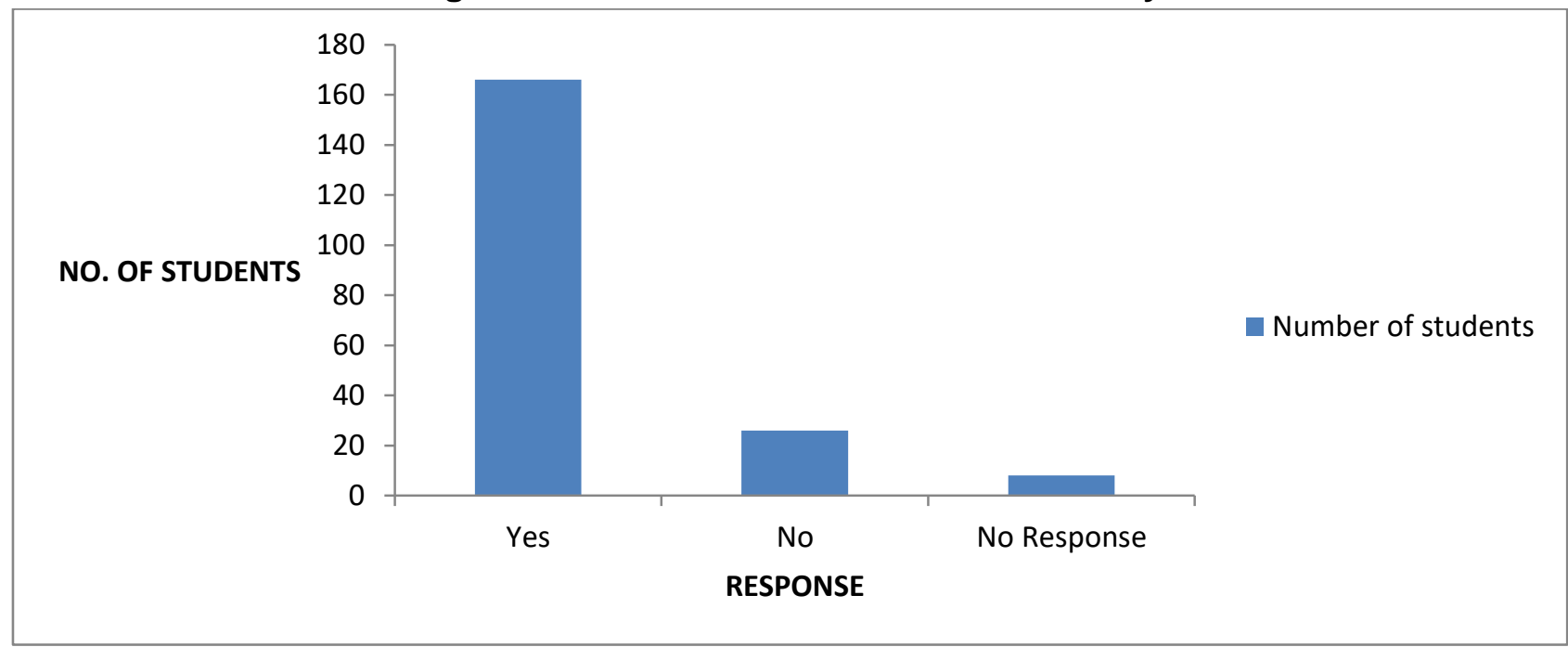

\section{Stress Management and Related Measures}

During the lockdown most of the students spent their time in different ways to overcome their stress. The 40 students said that they are reading their course books because their exam has not been completed. Apart from this 22 percent students are also watching TV with their regular study at home. Whereas 02 percent students have reported that they also consulted with doctor online how to overcome this situation. The details of responses are given in the following table.

Table 05: Stress Management and Related Stress

\begin{tabular}{|l|c|c|}
\hline Cope Up & Number of Students & Percentage (\%) \\
\hline Watching TV & 44 & 22 \\
\hline Study & 26 & 13 \\
\hline Sleeping & 10 & 05 \\
\hline Reading Course Book & 80 & 40 \\
\hline Reading Other Book & 12 & 06 \\
\hline Consult With Doctors & 04 & 02 \\
\hline Help to Home Work & 16 & 08 \\
\hline Other & 08 & 04 \\
\hline Total & 200 & 100 \\
\hline
\end{tabular}

Source: Primary survey (online mode) done by author, 2020 
Figure 04: Stress Management and Related Stress

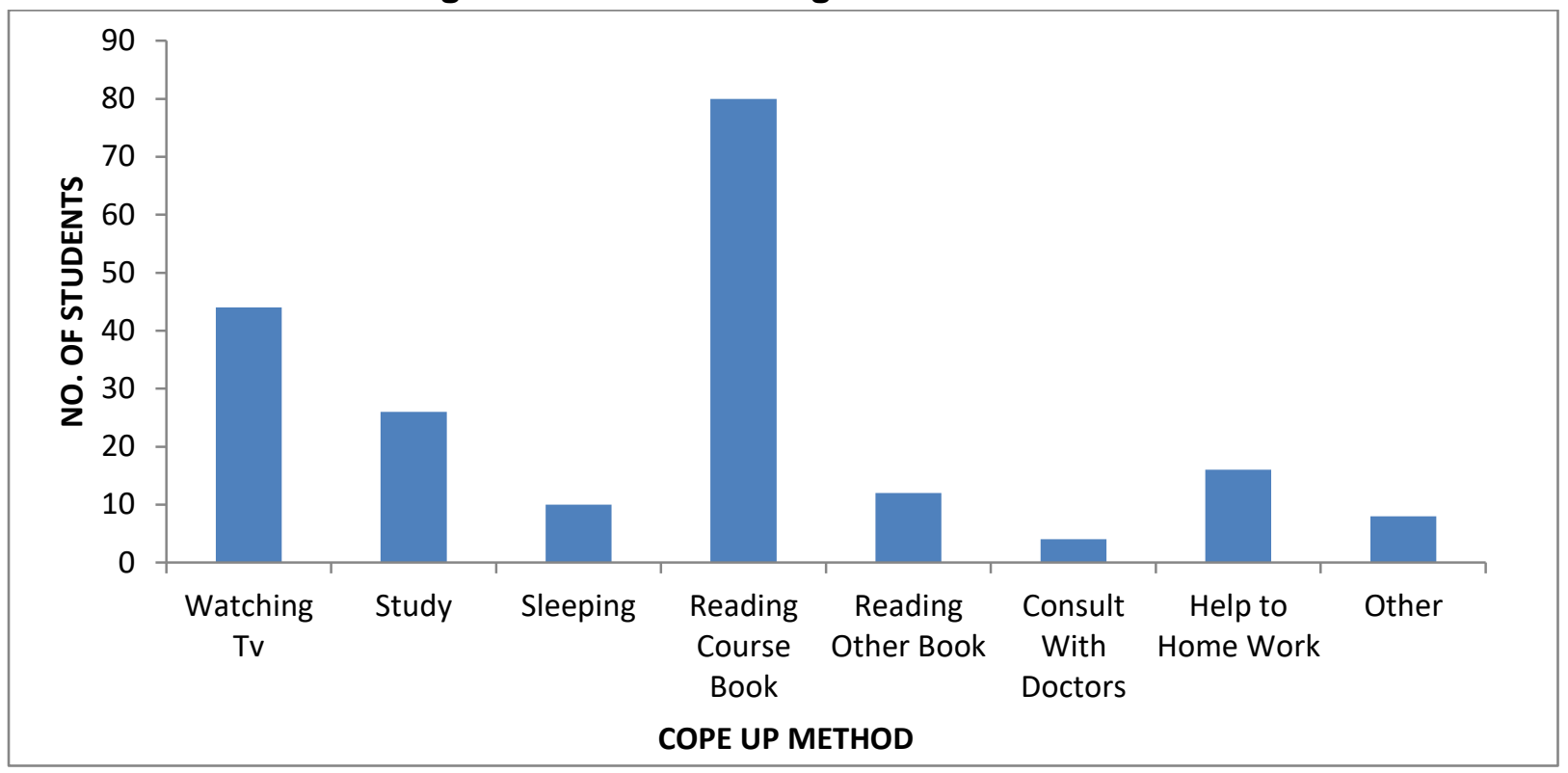

\section{Support from Teachers}

The postponement of the examinations is also causing frustration and stress among most of the students. These different kinds of tensions disrupt the sleep time of the students. About 65 per cent students reported that teachers' supported through WhatsApp group and online guidance which were really very useful. They get good number of notes and study materials from their teachers. This was very helpful for them, whereas 25 per cent students don't know about online support from teachers. This may be possible that they don't have smart phone. The details are given below:

Table 06: Support from Teacher

\begin{tabular}{|l|c|c|}
\hline Response & Number of Students & Percentage (\%) \\
\hline Yes & 130 & 65 \\
\hline No & 20 & 10 \\
\hline Don't know & 50 & 25 \\
\hline Total & 200 & 100 \\
\hline
\end{tabular}

Source: Primary survey (online mode) done by author, 2020

About 25 percent Students got course materials from teachers through WhatsApp group. Whereas 38 percent students said that they received You-tube video lecture. This You-tube lecture video was very helpful for them. Apart from this 25 percent received other material related to their course from the group. The details are given in the following table.

Table 07: Support Type from Teacher

\begin{tabular}{|l|c|c|}
\hline Support Category & Number of Students & Percentage (\%) \\
\hline Received lecture through WhatsApp Group & 50 & 25 \\
\hline Received video through you tube & 76 & 38 \\
\hline Direct ccounselling & 06 & 3 \\
\hline $\begin{array}{l}\text { Received oother mmaterials links tthrough } \\
\text { WhatsApp ggroup }\end{array}$ & 50 & 25 \\
\hline Other & 20 & 10 \\
\hline Total & 200 & 100 \\
\hline
\end{tabular}

Source: Primary survey (online mode) done by author, 2020 


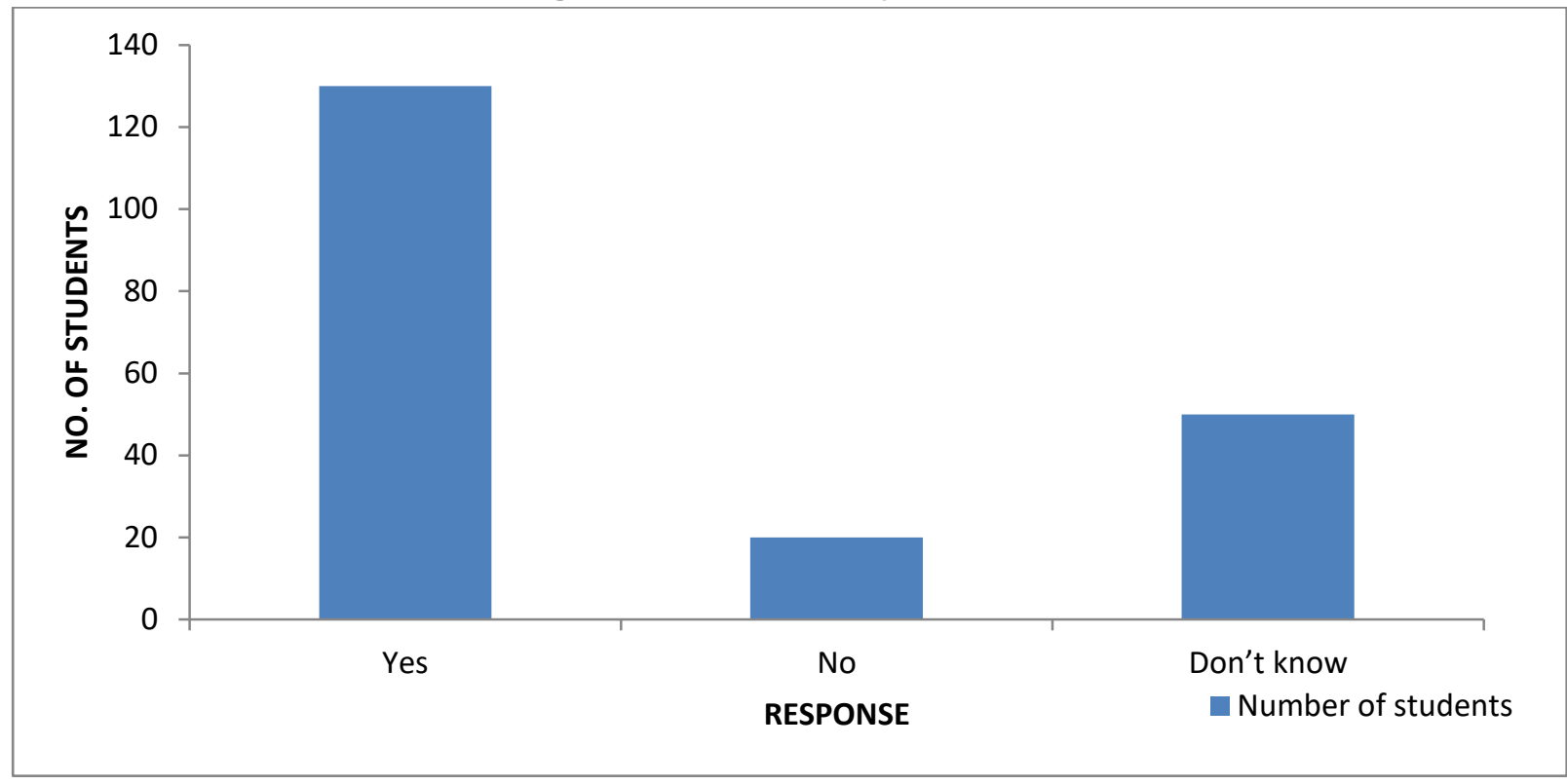

\section{Parents Support}

Parent's moral support was very important to boost the moral support of the children. They continuously motivated them to have patience and concentrate on their study and keep in touch with their teachers. About 96 per cent students agreed that their family support was very important. They are spending most of their time with families due to lockdown. The details are given in the following table.

Table 08: Support from Parents

\begin{tabular}{|l|c|c|}
\hline Response & Number of Students & Percentage (\%) \\
\hline Yes & 192 & 96 \\
\hline No & 04 & 02 \\
\hline Can't say & 04 & 02 \\
\hline Total & 200 & 100 \\
\hline
\end{tabular}

Source: Primary survey (online mode) done by author, 2020

\section{Support from Friends}

During the lockdown friends online support was also very important. They keep in touch all the time and share most of the academic conversations. The following table shows that 70 per cent students got support from their friends. Whereas 20 per cent said that they don't get any support from the fellow-students.

Table 09: Support from Friends

\begin{tabular}{|l|c|c|}
\hline \multicolumn{1}{|c|}{ Response } & Number of Students & Percentage (\%) \\
\hline Yes & 140 & 70 \\
\hline No & 40 & 20 \\
\hline Can't say & 20 & 10 \\
\hline Total & 200 & 100 \\
\hline
\end{tabular}

Source: Primary survey (online mode) done by author, 2020

\section{Leisure Time Spent}

The students spent leisure time in different ways. About 30 per cent said that they passed their leisure time watching TV. The details are given in the following table. 
Table 10: Leisure Time Spent

\begin{tabular}{|l|c|c|}
\hline Category & Number of Students & Percentage (\%) \\
\hline Watching TV & 60 & 30 \\
\hline Talk to Family Members & 10 & 05 \\
\hline Talk to Friends Through Mobile & 30 & 15 \\
\hline Talk to Our Teacher Through Mobile & 04 & 02 \\
\hline Sleeping & 20 & 10 \\
\hline Video Game/ Mobile Game & 56 & 28 \\
\hline Reading News Paper & 10 & 05 \\
\hline Other & 10 & 05 \\
\hline Total & 200 & 100 \\
\hline
\end{tabular}

Source: Primary survey (online mode) done by author, 2020

Figure 06: Leisure Time Spent

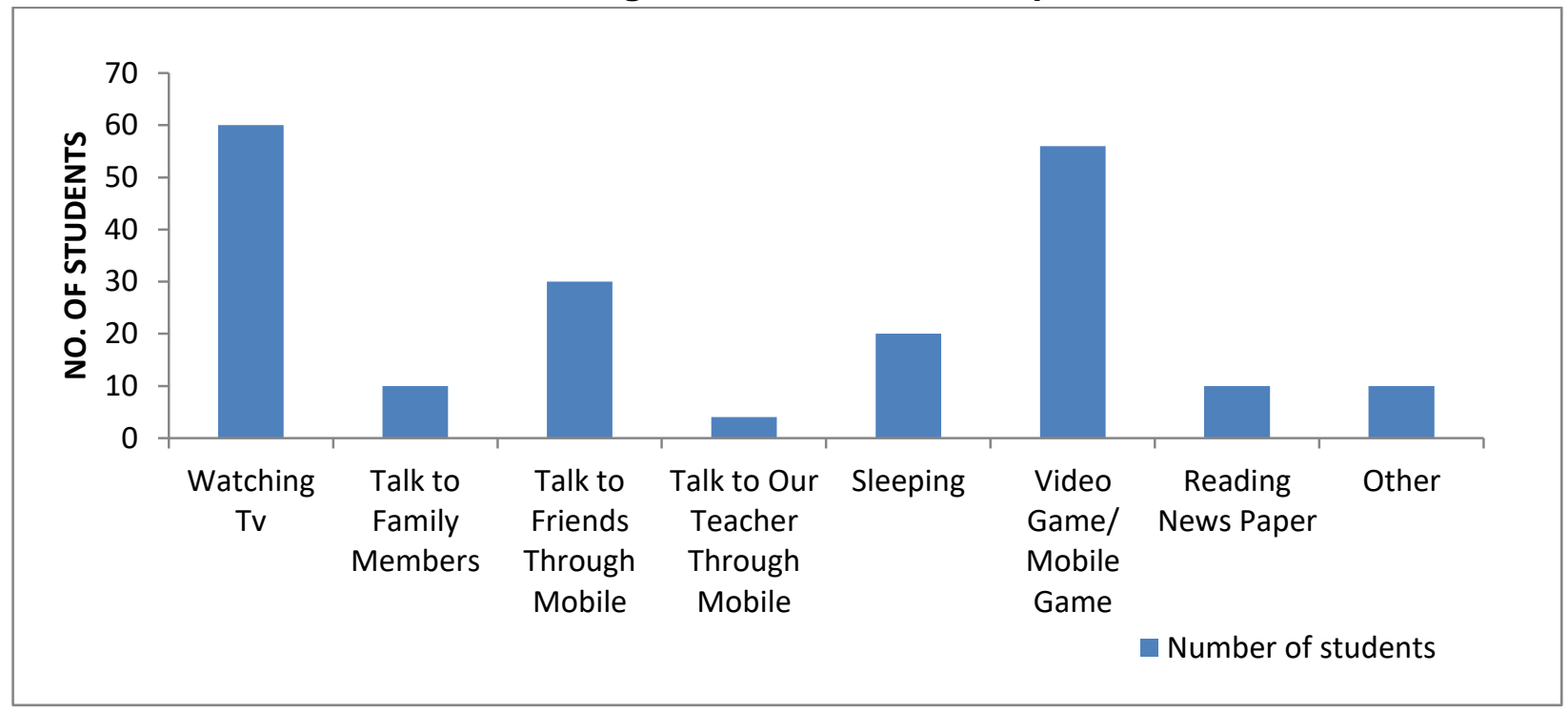

\section{Conclusion and Suggestions}

From the above survey, we see that how stress affects man's personal life and organizational life. Thus stress necessarily need to be coped with or effectively managed to minimize its undesirable consequences. The way to keep oneself stress-free and rejuvenate is summed up as under:

Meditation: "Meditation is a practice of concentrated focus upon a sound, object, visualization, the breath, movement, or attention itself in order to increase awareness of the present moment, reduce stress, promote relaxation, and enhance personal and spiritual growth." Meditation technique is to be used every day to quite the mind and bring a state of deep relaxation. When the conscious mind is calm and peaceful without worries or chattering thoughts people become open to insight and clarity. Hence, meditation is the best way to control stress. People, who meditate regularly, will learn to relax their mind, body and soul. Meditations cost nothing. If one learns meditation and practices regularly he is certainly away from stress.

Physical Exercise: Physical activities are always good for health, and help to bring down the stress level. Regular walk or skipping or jogging is recommended, or whatever the physical activity will surely help to reduce the ill effects of stress.

Learn to Relax: It is good to learn to relax by way to deep breathing exercise, and muscle tension reduction exercise. Hence, though-out the day, talking mini brakes, and sitting comfortably will help 
to reduce tension a little bit. Organizations should, arrange to provide ergonomically designed furniture to reduce time and motion between workouts, and provide treadmill to their workers to have a stroll. This could particularly be provided in the top profile officer's cabin, they can relax between long hours.

Practice Acceptance: Many people get distressed by thinking they cannot accept. Try to learn what is practically possible and try to accept people by understanding their feeling and beliefs.

Get Organized: It is always good to maintain a realistic schedule of daily activities that includes time of work, sleep, relationship, and recreation. Preparing a to-do-list with priority will help to reduce stress level to a certain extent.

To sum up, stress can not be altogether erased from our life as it will appear in some form or the other for some reason or the other. So, all we can do is find ways to ease ourselves in whatever way we can manage to do it best.

\section{References}

1. www.who.org

2. www.epaper.com

3. https://www.thehindu.com/news/cities/chennai/helpful-numbers-in-thesetimes/article31323032.ece

4. https://www.thehindu.com/life-and-style/what-mental-health-experts-say/article31185530.ece

5. services:https://www.thehindu.com/news/cities/chennai/helpful-numbers-in-thesetimes/article31323032.ece 